\title{
Gemlik Körfezi (Marmara Denizi, Bursa) Balık Tür Çeşitliliği Üzerine Bir Araştırma
}

\author{
Figen Esin KAYHAN*, Nilüfer BÜYÜKURGANCI \\ Marmara Üniversitesi Fen Edebiyat Fakültesi Biyoloji Bölümü, 34722, Kadıköy-Istanbul
}

\begin{abstract}
$\ddot{\mathbf{O z}}$
Bu çalışmada, Gemlik Körfezi’nde (Marmara Denizi, Bursa) yaşayan deniz balıklarının çeşitliliği familya ve tür bazında incelenmiştir. İncelenen balık örnekleri Gemlik Körfezi’nde avlanan yerel balıkçılardan Ocak 2010 ile Ocak 2011 tarihleri arasında her on beş günde bir toplanmıştır. Balık örnekleri Marmara Üniversitesi Zooloji Laboratuvarına getirilmiştir. Balık örneklerinin tür teşhisi, dış vücut özelliklerine göre ve ulusal/uluslararası kaynaklara göre yapılmış ve dağılımları hakkında bazı bilgiler edinilmiştir. Bu çalışma sonucunda Gemlik Körfezi'nde 36 adet familyaya ait 67 adet balık türü tespit edilmiştir.
\end{abstract}

Anahtar kelimeler: Balık çeşitliliği, Marmara Denizi, Gemlik Körfezi, ihtiyofauna

\section{An Investigation on Local Fish Diversity of Gulf of Gemlik (Marmara Sea, Bursa)}

\begin{abstract}
In this study, the marine fish diversity of Gulf of Gemlik (Marmara Sea, Bursa) was investigated based on the family diversity and species. Fish samples were collected within 15 days periods from local fishermens of the Gulf of Gemlik between January 2010 and January 2011. Fish samples were transported to Marmara University Zoology Laboratory. Fish samples were transported to Marmara University Science and Art Faculty, Zoology Laboratory. Fish species were identified with external body features and classified based on the systematic descriptions according to national and international datas, also given some information about their distribution. As a result of our study, totaly 36 families include 67 species from the Gulf of Gemlik were determined.
\end{abstract}

Keywords: Fish diversity, Gulf of Gemlik, Marmara Sea, Ichthyofauna

\section{GİRIŞ}

Denizlerde değişmez bir kural varsa o da, biyoçeşitliliğin sürekli değişmesidir. Deniz biotası geçmişten günümüze hem insan eliyle hem de iklim değişiklikleri gibi doğal nedenlerle sürekli değişime uğramıştır. İklim değişiklikleri zaman zaman denizlerdeki biyoçeşitlilik için tehdit olmakla birlikte uzun vadede birçok olumlu sonuçlara da neden olmuştur. Süregelen iklimsel döngüler hem evrimsel hem de ekolojik skala yönünden çeşitliliği arttırmıştır [1,2,3,4].

Gemlik Körfezi, Marmara Denizi'nin güney doğusunda genişliği batıya doğru artan Marmara Denizi'nin körfezlerinden biridir. Marmara Denizi'nin genelinde olduğu gibi Gemlik Körfezi'nde de üstte Karadeniz suyu altta Akdeniz suyu olmak üzere iki tabakalı akıntı mevcuttur. Marmara Denizi'nin çoğu bölgesi az kirli sınıfına girmekle birlikte, Bandırma,
Gemlik ve İzmit körfezleri orta kirli fakat ağır kirli duruma eğilimli su sınıfında olduğu belirtilmektedir [5].

Körfez çevresinde 11 yerleşim merkezi bulunmaktadır. En büyük yerleşim yeri ise Bursa iline bağlı olan Gemlik İlçesi'dir. Körfez çevresindeki yerleşim yerlerinde gırgır, manyat, uzatma ağları, çapari, fanyalı ağlar kullanılarak balıkçılık yapılmaktadır. Bölgede genellikle amatör düzeyde olta balıkçılığı ve kıyı balıkçılığı görülmektedir. Avlanan balıklar körfezdeki tüm balık tüketimi için yetersiz olup Bursa'daki balık halinden ve Bandırma'dan balık ihtiyacı karşllanmaktadır. Körfez; yerleşimin kıyı boyunca yüksek olması, turizmin hızlı gelişimi, nehir girdileri, liman bölgeleri, evsel ve fabrika kökenli atıklar, deniz trafiğinden kaynaklanan çeşitli atıklardan etkilenmektedir $[6,7,8]$. Bu nedenle balıkçılar tarafından eskiye oranla bölgede daha az balık türüne rastlandığı söylenmektedir [9]. 


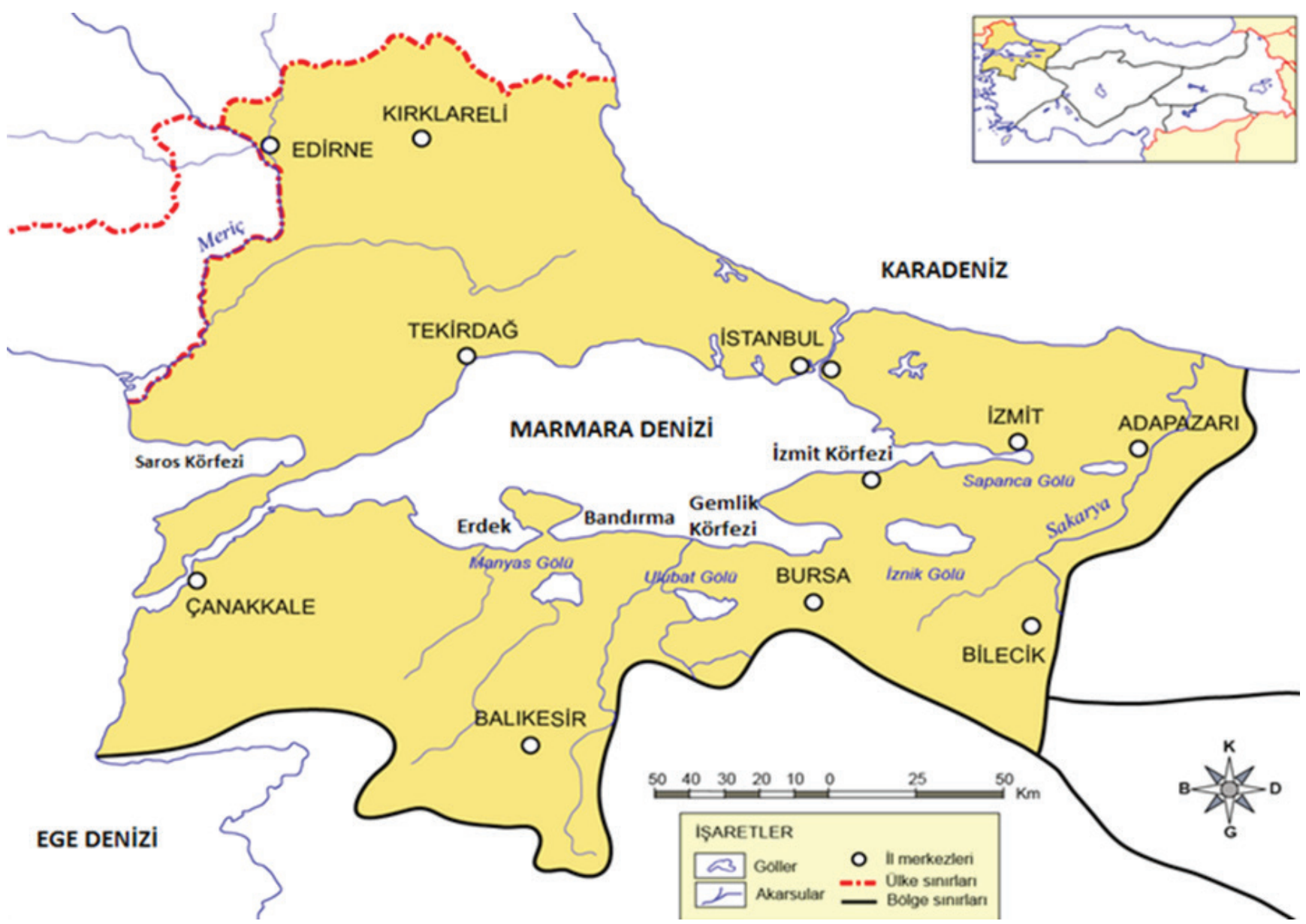

Şekil 1. Gemlik Körfezi (Marmara Denizi) ve Marmara Bölgesi Havzası genel görünümü

$\mathrm{Bu}$ çalışmada Gemlik Körfezi'nde avlanan yerel balıkçllardan bilgi alınarak [9] ve FishBase'den (balıkların taksonomisi ve dağılımlarını kapsayacak şekilde bugün dünyadaki balık türlerinin yaklaşık yarısını içine alan internet veritabanı) bölgedeki balık dağılımı güncellenerek körfezdeki balık tür çeşitliliğinin ortaya konulması amaçlanmıştır [10]. Böylece, körfezdeki mevcut balık türlerinin tam bir listesi hazırlanarak ve balıkların görülme sıklığı tabloda gösterilerek konuyla ilgili araştırmacılara kaynak liste oluşturulması sağlanmaya çalışılmıştır. Gemlik Körfezi'nin balık tür çeşitliliği, bölgenin ekolojik gelişimi ve balık faunasının tam olarak tespit edilmesi ve yerel/göçmen türlerin tespit edilmesi, lesepsiyen türlerin izlenmesi üzerine daha detaylı inceleme, gözlem ve araştırmalara gereksinim olduğu düşünülmektedir.

\section{MATERYAL VE METOD}

Bu çalışmada kullanılan materyal olan balıklar, Gemlik Körfezi'nde avlanan ve balık ticareti yapan yerel balıkçılardan
Ocak 2010-Ocak 2011 tarihleri arasında her 15 günde bir alınmıştır. Elde edilen balıklar etiketlenmiş ve \% 70 etanol veya \% 4-6 formalin içerisinde Marmara Üniversitesi, Fen-Edebiyat Fakültesi, Biyoloji Bölümü Zooloji Anabilim dalı araştırma laboratuvarına getirilerek tür tespiti çalışmalarına başlanmıştır. Bu çalışmada kullanılan metodda ise elde edilen türlerin sistematik teşhisleri Nelson'a göre [11], türlerin adlandırılmaları ise Eschmeyer'e [12,13] göre yapılmıştır. Ayrıca, Türkiye denizlerindeki dağılımlarının belirlenmesinde ulusal kaynaklar kullanılmıştır [14,15].

\section{BULGULAR}

Yapılan bu araştırma sonucunda Marmara Denizi'nin önemli körfezlerinden biri olan Gemlik Körfezi'nde 36 adet familyaya ait toplam 67 adet balık türü tespit edilmiştir. 36 familyaya ait 67 balık türünün adları ve bu balık türlerinin körfezde görülme sıklıkları FishBase dikkate alınarak Tablo.1'de gösterilmektedir. 
Tablo.1 Gemlik Körfezi’nden Ocak 2010- Ocak 2011 tarihleri arasında elde edilen 36 familyaya ait 67 balık türünün listesi.

\begin{tabular}{|c|c|c|c|c|c|c|c|c|c|}
\hline \multicolumn{10}{|c|}{ GEMLİK KÖRFEZI'NDE GÖRÜLEN BALIK TÜRLERI VE GÖRÜLME SIKLIĞI } \\
\hline SINIF & TAKIM & FAMILYA & TÜR & 0 & 1 & 2 & 3 & 4 & 5 \\
\hline \multirow{3}{*}{ 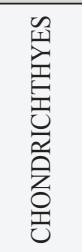 } & CARCHARHINIFORMES & TRIAKIDAE & Galeorhinus galeus Linnaeus, 1758-Camgöz & & + & & & & \\
\hline & SQUALIFORMES & SQUALIDAE & Squalus acanthias Linnaeus, 1758- Mahmuzlu Camgöz & & & & + & & \\
\hline & RAJIFORMES & RAJIDAE & Raja clavata Linnaeus, 1758 - Vatoz Balı̆ğ & & & + & & & \\
\hline \multirow{28}{*}{ 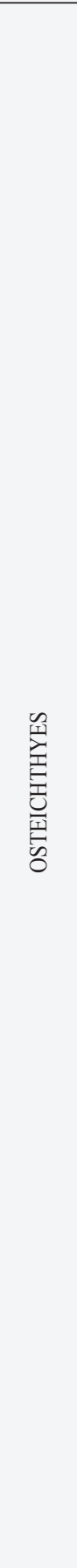 } & \multirow{3}{*}{ ANGUILLIFORMES } & ANGUILLIDAE & Anguilla anguilla Linnaeus, 1758 -Yılan Balığı & & & & & & + \\
\hline & & CANGRIDAE & Conger conger Linnaeus, 1758 - Mığrı Balığı & & & & + & & \\
\hline & & OPHİCHTHIDAE & Echelus myrus Linnaeus, 1758-Mirmır & & + & & & & \\
\hline & \multirow{6}{*}{ CLUPEIFORMES } & \multirow{5}{*}{ CLUPEIDAE } & Sardinella maderensis Lowe, 1838-Sardalya & & + & & & & \\
\hline & & & Sardinella aurita Valenciennes,1847-sardalya & & + & & & & \\
\hline & & & Sardina pilchardus Walbaum, 1792-Sardalya & + & & & & & \\
\hline & & & Alosa agone Scopoli, 1786 - Tirsi & & + & & & & \\
\hline & & & Sprattus sprattus Linnaeus,1758- Papalina(Çaça) Balığ & & & & & & + \\
\hline & & ENGRAULIDAE & Engraulis encrasicolus Linnaeus, 1758 - Hamsi Balığ 1 & & & & + & & \\
\hline & BELONIFORMES & BELONIDAE & Belone belone Linnaeus, 1761-Zargana & & & & & & + \\
\hline & ZEIFORMES & ZEIDAE & Zeus faber faber Linnaeus, 1758 -Dülger & & + & & & & \\
\hline & MUGILIFORMES & MUGILIDAE & Mugil cephalus Linnaeus, $1758 \mathrm{KEFAL}$ & & + & & & & \\
\hline & \multirow[b]{2}{*}{ ATHERINIFORMES } & \multirow[b]{2}{*}{ ATHERINIDAE } & Atherina boyeri Risso,1810- Gümüş & & & & & & + \\
\hline & & & Atherina presbyter Cuvier,1829 Gümüş & + & & & & & \\
\hline & \multirow{14}{*}{ PERCIFORMES } & MORONIDAE & Dicentrarchus labrax Linnaeus, 1758 - Levrek Balığ & & & & + & & \\
\hline & & SERRANIDAE & Serranus hepatus Linnaeus, 1758- Benekli hani balı̆̆ & & + & & & & \\
\hline & & POMATOMIDAE & Pomatomus saltatrix Linnaeus, 1766 - lüfer & & + & & & & \\
\hline & & \multirow{2}{*}{ CARANGIDAE } & Trachurus mediterraneus Steindachner, 1868 - İstavrit & & & & & & + \\
\hline & & & Trachurus trachurus Linnaeus, 1758 - Karagöz İstavrit & & + & & & & \\
\hline & & \multirow{9}{*}{ SPARIDAE } & Sparus aurata Linnaeus, 1758 - Çipura & & + & & & & \\
\hline & & & $\begin{array}{l}\text { Diplodus vulgaris Geoffroy Saint-Hilaire, 1817- Kara- } \\
\text { göz balığı }\end{array}$ & & + & & & & \\
\hline & & & Spicara maena Linnaeus, 1758- ̇̇zmarit & & + & & & & \\
\hline & & & Spicara smaris Linnaeus, 1758- İstrongiloz & & & & + & & \\
\hline & & & Spicara smaris Linnaeus, 1758- İstrongiloz & & & + & & & \\
\hline & & & Diplodus annularis Linnaeus, 1758- Isparoz & & + & & & & \\
\hline & & & Boops boops Linnaeus, 1758- Kupes Balığı & & + & & & & \\
\hline & & & Pagrus pagrus Linnaeus, 1758 - Mercan Balı̆̆ & & + & & & & \\
\hline & & & Dentex dentex Linnaeus, 1758 Sinagrit & & + & & & & \\
\hline
\end{tabular}




\begin{tabular}{|c|c|c|c|c|c|c|c|c|c|}
\hline \multicolumn{10}{|c|}{ GEMLIKK KÖRFEZI'NDE GÖRÜLEN BALIK TÜRLERİ VE GÖRÜLME SIKLIĞI } \\
\hline SINIF & TAKIM & FAMILYA & TÜR & $\mathbf{0}$ & 1 & 2 & 3 & 4 & 5 \\
\hline \multirow{35}{*}{ 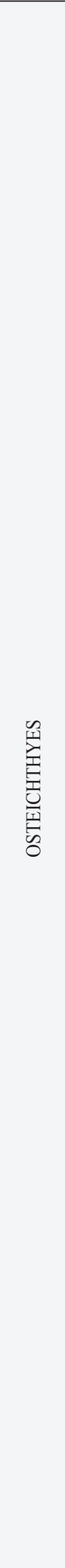 } & \multirow{23}{*}{ 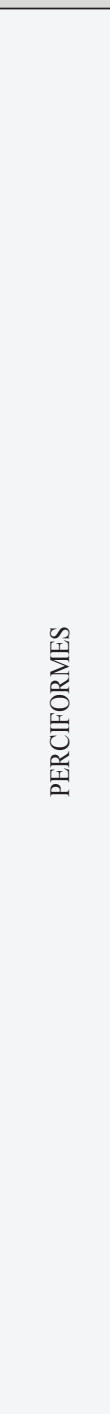 } & \multirow{2}{*}{ SCIAENIDAE } & Sciaena umbra Linnaeus, 1758 - Eşkina & & & & & & + \\
\hline & & & Umbrina cirrosa Linnaeus, 1758 - Minekop & & & & & & + \\
\hline & & \multirow{2}{*}{ MULLIDAE } & Mullus barbatus barbatus Linnaeus, 1758-Barbunya & & + & & & & \\
\hline & & & Mullus surmuletus Linnaeus, 1758- Tekir & & & & + & & \\
\hline & & \multirow{4}{*}{ LABRIDAE } & Labrus mixtus Linnaeus, 1758 -Lapin I & & & & + & & \\
\hline & & & Labrus merula Linnaeus, 1758 -Lapin II & + & & & & & \\
\hline & & & Labrus viridis Linnaeus, 1758 - Lapin III & + & & & & & \\
\hline & & & Labrus bergylta Ascanius, 1767- Kikla & & + & & & & \\
\hline & & \multirow[b]{2}{*}{ TRACHINIDAE } & Trachinus radiatus Cuvier, 1829 - İskorpit,çarpan & & + & & & & \\
\hline & & & $\begin{array}{l}\text { Trachinus draco Linnaeus, } 1758 \text { - Kayabalığı, Trakonya, } \\
\text { Barsan }\end{array}$ & & & & & & + \\
\hline & & URANOSCOPIDAE & Uronoscopus scaber Linnaeus, 1758 - Kurbağa Balığ & & + & & & & \\
\hline & & \multirow{6}{*}{ BLENNIIDAE } & Blennius gattorugine Brünnich, 1763 - Horazbina I & + & & & & & \\
\hline & & & Blennius ocellaris Linnaeus, 1758 Horazbina II & & + & & & & \\
\hline & & & Salaria pavo Risso, 1810 - Horazbina III & & & & & + & \\
\hline & & & Parablennius sanguinolentus Pallas, 1814- Horazbina IV & & & & & & + \\
\hline & & & Parablennius tentacularis Brünnich, 1768 - Horazbina V & & & & & & + \\
\hline & & & Coryphoblennius galerita Linnaeus, 1758 - Horazbina VI & & + & & & & \\
\hline & & \multirow{2}{*}{ GOBIIDAE } & Gobius niger Linnaeus, 1758 - Kömürcü Kayası Balığ 1 & & & & & & + \\
\hline & & & Gobius cobitis Pallas 1814- Kaya balığ1 & & & & & & + \\
\hline & & \multirow{3}{*}{ SCOMBRIDAE } & Scomber japonicus Houttuyn, 1782 - Kolyoz & & + & & & & \\
\hline & & & Sarda sarda Bloch, 1793 - Palamut & & & & + & & \\
\hline & & & Scomber scombrus Linnaeus, 1758 - Uskumru & & & & & & + \\
\hline & & XIPHIIDAE & Xiphias gladius Linnaeus, 1758- Kılıç balığ 1 & & + & & & & \\
\hline & \multirow{12}{*}{ 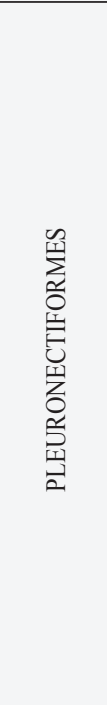 } & \multirow{2}{*}{ SCOPHTHALMIDAE } & Psetta maxima Linnaeus, 1758 - Kalkan & & & & & + & \\
\hline & & & Lepidorhombus boscii Risso, 1810 - Pisi & & + & & & & \\
\hline & & CITHARIDAE & Citharus linguatula Linnaeus, 1758 - Pisi & & + & & & & \\
\hline & & \multirow{6}{*}{ SOLEIDAE } & Solea solea Linnaeus, 1758 - Dil balığı & & + & & & & \\
\hline & & & Buglossidium luteum Risso, 1810 Dil & & & & & & + \\
\hline & & & Microchirus ocellatus Linnaeus, 1758 Dil & + & & & & & \\
\hline & & & Monochirus hispidus Rafinesque,1814 Dil & + & & & & & \\
\hline & & & Synapturichthys kleinii Risso ,1827 Dil & + & & & & & \\
\hline & & & Solea lascaris Risso, 1810 Dil & & + & & & & \\
\hline & & \multirow{3}{*}{ BOTHIDAE } & Arnoglossus kessleri Schimidt, 1915 Dil & & & & & & \\
\hline & & & Arnoglossus laterna Walbaum, 1792 Dil & & & & + & & \\
\hline & & & Bothus podas Delaroche, $1809 \mathrm{Dil}$ & + & & & & & \\
\hline
\end{tabular}




\begin{tabular}{|c|c|c|c|c|c|c|c|c|c|}
\hline \multicolumn{10}{|c|}{ GEMLİK KÖRFEZI'NDE GÖRÜLEN BALIK TÜRLERİ VE GÖRÜLME SIKLIĞI } \\
\hline SINIF & TAKIM & FAMILYA & TÜR & 0 & 1 & 2 & 3 & 4 & 5 \\
\hline \multirow{12}{*}{ 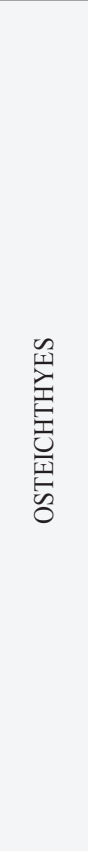 } & \multirow{7}{*}{ 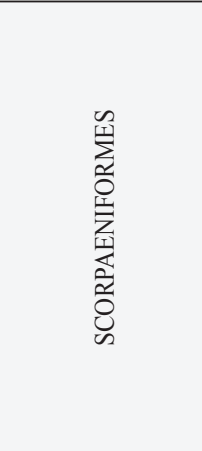 } & \multirow{3}{*}{ SCORPAENIDAE } & Scorpaena scrofa Linnaeus, 1758 - Lipsoz & & + & & & & \\
\hline & & & Scorpaena notata Rafinesque, 1810 İskorpit & + & & & & & \\
\hline & & & Scorpaena porcus Linnaeus, 1758 - İskorpit & & + & & & & \\
\hline & & \multirow{4}{*}{ TRIGLIDAE } & Chelidonichthys lucerna Linnaeus, 1758 - Kırlangıç & & & & + & & \\
\hline & & & Trigla lyra Linnaeus, 1758 - Öksüz Balığ & & + & & & & \\
\hline & & & Trigloporus lastoviza Bonnaterre, 1788 - Mazak & & & & + & & \\
\hline & & & $\begin{array}{l}\text { Eutrigla gurnardus Linnaeus, } 1758 \text { - Benekli Kırlangıç } \\
\text { Balı̆̆ı }\end{array}$ & & & & + & & \\
\hline & \multirow{4}{*}{ 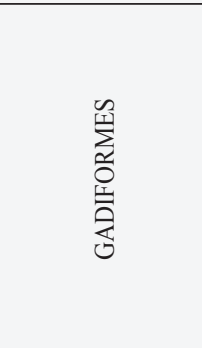 } & \multirow{2}{*}{ GADIDAE } & $\begin{array}{l}\text { Merlangius merlangus merlangus Linnaeus, } 1758 \text { - Ba- } \\
\text { kalyaro Kara mezgit }\end{array}$ & & & & + & & \\
\hline & & & $\begin{array}{l}\text { Merlangius merlangus euxinus Nordmann, } 1840 \text { Çıplak } \\
\text { Mezgit }\end{array}$ & & & & + & & \\
\hline & & MERLUCCIIDAE & Merluccius merluccius Linnaeus, 1758- Berlam Balığ & & + & & & & \\
\hline & & LOTIDAE & $\begin{array}{l}\text { Gaidropsarus mediterraneus Linnaeus, } 1758 \text { - Gelincik } \\
\text { Balı̆̆ }\end{array}$ & & + & & & & \\
\hline & LOPHIIFORMES & LOPHIIDAE & Lophius piscatorius Linnaeus, 1758 - Fener Balığ1 & & & & + & & \\
\hline
\end{tabular}

\section{TARTIŞMA VE SONUÇ}

Literatür araştırması sırasında Gemlik Körfezi'nde balık ve su ürünleri çeşitliliği açısından daha önce yapılan bir çalışmaya rastlanmamıştır. Bu nedenle bu araştırma bölgede yapılmış ilk araştırma olma niteliğindedir. $\mathrm{Bu}$ durumun elde ettiğimiz tür listesinin daha uzun olmasına engel olduğunu düşünüyoruz. Bursa ilinde deniz suyunun hem karasal kirletici kaynaklar hem de noktasal kirletici kaynaklar tarafindan kirletildiği rapor edilmiştir. Gemlik Körfezi'ni etkileyen karasal kirletici kaynaklar Gölağı deresi, Karsak deresi ve yerleşim yerlerinden deşarj edilen atıksular ve sanayi kuruluşlarının deşarjlarıdır. Noktasal kirletici kaynak olarak da genellikle derin deniz deşarjı gösterilmiştir [5,6,16,17]. Bilecenoğlu ve ark. (2014) Türkiye deniz balıkları faunası üzerine yaptıkları araştırmalarında Türkiye denizleri genelinde farklı familyalara ait 512 adet balık türü olduğunu belirtmişlerdir [18]. İskenderun ve Mersin Körfezleri'nde 2010-2012 yılları arasında yapılan bir araştırmada özellikle yabancı balık miktarlarında artış olduğu belirtilmiştir. Daha önce aynı bölgelerde yapılan çalışmalarda körfezlere geçiş yapan 34 familyaya ait 52 yabancı balık türü varken, sadece yabancı balıkların saptanması amaciyla 2010-2012 tarihleri arasında yapılan diğer bir araştırmada 30 familyaya ait 43 tür bulunduğu rapor edilmiştir. Bu durum son yıllarda küresel ısınma ve etkileri sonucu Süveyş Kanalı aracılığıyla Kızıldeniz'den ve Cebelitarık Boğazı aracılığıyla Atlantik'ten gelen yabancı balıkların Akdeniz ekosistemine fazlaca giriş yapması olarak açıklanmaktadır [19].

Çoker ve Akyol (2014) Gökova Körfezi (Güneydoğu Ege Denizi) balık tür çeşitliliği üzerine yaptıkları bir değerlendirmede körfezde kıyı balıkçıllğı temelli toplam 95 familyaya ait 205 balık türü saptamışlardır [20]. Biz çalışmamızda toplam 36 familyaya ait 67 balık türü tespit ettik. Daha az sayıda balık türünün bulunmasının sebebi, Gemlik Körfezi'nin antropojenik olarak daha fazla kirlenen ve ekolojik dengenin aşırı zorlandığı düşünülen bir içdeniz olan Marmara Denizi'ne ait bir körfez olmasıdır. Gemlik Körfezi'nde daha önce balık faunası ile ilgili bilimsel araştırmaların çok az ya da hiç olmaması, mevsimsel bazı zorluklar ve derin deniz türlerinin elde edilememesi gibi sebepler tür listemizin daha uzun olmasını engellemiş olabilir. Elde ettiğimiz listede şüpheli türler de olabilir. Müze kayıtlarının olmaması nedeniyle şüpheli türlerin doğruluğu kontrol edilememiştir. Aslında bu durum üniversitelerimizin ilgili bölümlerinin balık biyoçeşitliliği konusunda daha hassas ve derin bazı araştırmalara girmesi gerektiğinin de bir işaretidir. Bulunan tür sayısının az olmasının asıl nedeni çalışma alanımız olan Gemlik Körfezi'nin küçük ve dar bir körfez olması ve antropojenik etkilere çok fazla maruz kalması olarak gösterilebilir. Ayrıca 1960'lı yıllardan itibaren hem endüstriyel 
hem de evsel atıklarla kirletilen bir iç denizimiz olan Marmara Denizi'nin kirlilik yükü de göz önünde bulundurulmalıdır $[5,16$,$] . Önceki yıllara ait herhangi bir veri olmamas1$ son durum hakkında kesin karar vermemizi elbette güçleştirmiştir. Körfez çevresindeki karasal bölgede rekreasyonal aktiviteler, yoğun tarımsal faaliyetler, gemilerin atık suları ve atmosferik taşınım/çökelme nedeniyle Gemlik Körfezi'nin kirleticilere oldukça yoğun şekilde maruz kaldığı gözlenmektedir [7]. Bu tarz aktiviteler esasen dünyada tüm kıyısal alanlarda izlenen durumlardır [2]. Bu nedenlerle, Marmara Denizi’nin tüm Türkiye su ürünleri üretimine katkıs1 son on yılda \% 22'lerden \% 6'lara kadar düşmüştür [16]. Körfezde balık tür çeşitliliği üzerine önceki yıllarda yapılmış kaynak çalışmalara rastlanmasa da, bölgedeki balıkçılardan alınan bilgiler balık tür çeşitliliğinin ve avlanan balık miktarının bölgede son yıllarda azaldığını işaret etmektedir [9]. Bu nedenle körfezden avlanan balıklar yerel halkın ihtiyacı karşılamamakta, Bandırma'dan, Bursa balık halinden tezgâhlara balık getirilmektedir. Çalışmamızın amaçlarından biri de Gemlik Körfezi'nin balık tür çeşitliliği hakkında bizden sonraki araştırmacılara fikir vermesidir. Bu çalışma Gemlik Körfezi'ndeki balıkçılık, olası ekolojik değişiklikler ve kıyısal ekosistemleri irdelemek ve gelecekte yapılacak araştırmalara ışık tutmak açısından önemli bir araştırmadır. Gemlik Körfezi'nin sucul biyoçeşitliliği, ekolojik gelişimi ve balık faunasının sürekli izlenmesi ve tam olarak tespit edilmesi üzerine daha detaylı inceleme ve araştırmalara gereksinim olduğu kanısındayız.

Marmara Denizi'nin önemli ve en büyük körfezi olan İzmit Körfezi’nde 2004-2005 yılları arasında yapılan bir araştırmada 2 familyaya ait 3 kıkırdaklı balık türü ve 31 familyaya ait 50 kemikli balık türü bulunmuştur. Ayrıca kıkırdaklı balıklardan olan ve daha önce Ege Denizi ve Akdeniz'de de bulunduğu rapor edilen Raja radula Marmara Denizi, İzmit Körfezi için yeni kayıt olarak bildirilmiştir [21]. Erdek Körfezi'nde (Marmara Denizi) 2000-2002 yılları arasında jüvenil balık popülasyonlarının kompozisyonu araştırılmıştır. Çalışmada körfezde seçilen 12 istasyonda jüvenil balıkların kommunite yapısı kalitatif ve kantitatif olarak değerlendirilmiştir. Ayrıca çalışmada türlerin dağılımı, bolluğu, ortalama kısmi baskınlığı, her bir türe ait birey sayısı, bulunma sıklığ tespit edilmiştir. Çalışma sonunda 38 familya ve 55 cinse ait 82 balık türü olduğu rapor edilmiştir. Gözlenen en yaygin türler Atherina boyeri, Atherina hepsetus ve Liza aurata olarak belirlenmiştir. Araştırmacılar Erdek körfezi'nin ihtiyofaunistik yönden çeşitliliğini halen korumakta olduğunu belirtmişlerdir [22]. Ayrıca yerel gazetelerden sevindirici bir haber ise Erdek ve Ocaklar mevkiinde denize 540 adet yapay resifin bırakılmasıdır. Yapay resifler sayesinde Erdek Körfezi'nde balık sayısı ve çeşitliliğinde artış olduğu bildirilmiştir [23,24]. Bat ve arkadaşları (2005) Türkiye'nin Orta Karadeniz kıyısı balıkları üzerine yaptıkları biyoçeşitlilik araştırmasında Sinop ve Samsun kıyı ve açıklarından toplam 44 familyaya ait 94 balık türü tespit etmişlerdir. Orta Karadeniz bölgesinde besin tuzu dengesinin bozulması sonucu bazı değişimler yaşandığını ve sırasıyla fitoplankton, zooplankton ve ihtiyoplanktonun kalite ve miktarlarında artış gözlediklerini belirtmişlerdir. Ayrıca araştırmacılar Acipencer persius türünün Orta Karadeniz bölgesi için yeni kayit olduğunu rapor etmişlerdir [25]. Antalya Körfezi'nde yapılan bir araştırmada toplam 37 familyaya ait 61 tür balık tespit edilmiştir [26]. Kır ve arkadaşları ise (2001) yine Antalya Körfezi'nde 18 familyaya ait 35 tür tespit etmiştir. Antalya limanında balıkçılar ve balıkçılıkla uğraşan kimseler tarafindan avlanan ve satılan balıklar ile ilgili herhangi bir kayıt tutulmaması gerçek rakamlar hakkında bilgi sahibi olmamızı engellemektedir [27]. Keza, 22.12.2010 tarihli 27793 sayılı Bakanlar Kurulu kararı ile özel çevre koruma bölgesi olarak kabul edilen Saroz Körfezi karasal ve denizel biyolojik çeşitliliğin araştırıldığı bir proje kapsamında biyotop sınıflandırması yanı sıra nesli tehlikede olan türlerin saptanması da amaçlanmıştır. Proje halen devam etmekte olup, Saroz Körfezi'nde nesli tehdit ve tehlikede olan tür ve habitatlar sınıflandırılmış, koruma önlemleri ortaya konulmaya çalışı1mıştır [28]. Marmara Denizi'ni ve Gemlik Körfezi'ni tehdit eden faktörler Marmara denizinin genel kirliliği, yerel yönetimlerin kıyı kültür birikiminin yetersiz olması, k1yılarda aşırı yapılaşma talebi, kaçak yapılaşma, izinsiz dolgu yapılması, akarsuların ve derelerin kirlenmesi, çok sayıda liman ve tersanenin varlığı olarak sayılabilir.

Sonuç olarak nüfusun hızla artması balık tüketiminin de artmasına neden olmuştur. Bu yüzden kontrolsüz avc1lık biyoçeşitliliği tehdit etmektedir. Ülkemiz denizlerinin sahip olduğu model ve zenginlikleri hakkında sürekli tarama, inceleme ve gözlemlere gereksinim vardır. Kaliteli protein arayışında olan insanların ellerindeki balık stoklarını uygun şekilde tüketmeleri gerekmektedir. Zaman zaman denizlerin belli bölgelerinin nadasa bırakılması bazı türlerin popülasyon sayılarının ciddi şekilde artmasına olanak sağlar. Keza son yıllarda sıklıkla bahsedilen balık boyu tartışmaları da ciddi şekilde takip edilmesi gereken bir sorundur. Bu konuda balıkçılar daha da bilinçlendirilmeli ve gerekirse sübvanse edilmelidir. Ancak bu şekilde balık stoklarımız hakkında gerçek bilgi sahibi olabiliriz. Aynı zamanda deniz ekosistemlerini ve biyoçeşitliliğin doğal dağılımını belirleyerek meydana gelen değişikliklerin etkilerini erken anlamak zorundayız. Sağlıklı bir sucul ekosistemin sürdürülebilirliği, ortamda yaşayan türlerin çeşitliliğine bağlıdır. 


\section{TEŞEKKÜR}

$\mathrm{Bu}$ araştırma Marmara Üniversitesi, Bilimsel Araştırma Projeleri Komisyonu tarafindan FEN-C-YLP-031110-0257 no'lu yüksek lisans projesi olarak desteklenmiştir.

\section{KAYNAKLAR}

[1] McLean D.L., Langlois T.J., Newman S.J., Holmes T.H., Birt M.J., Bornt K.R., Bond T., Collins D.L., Evans S.N., Travers M.J., Wakefield C.B., Babcock R.C., Fisher R. (2016). Distribution, abundance, diversity and habitat associations of fishes across a bioregion experiencing rapid coastal development. Estuarine, Coastal and Shelf Science. 178, 36-47.

[2] Riera R., Menci C., Sanabria-Fernandez J.A., Becerro M.A. (2016). Do recretional activities affect coastal biodiversity? Estuarine, Coastal and Shelf Science. 178,129-136.

[3] Colburn L.L., Jepson M., Weng C., Seara T., Weiss J., Hare J.A. (2016). Indicators of climate change and social vulnerability in fishing dependent communities along the Eastern and Gulf Coasts of the United States. Marine Policy. doi.org/10.1016/j.marpol.2016.04.030

[4] Bianchi C.K., Morri C. (2000). Marine biodiversity of the Mediterranean Sea: Situation, problems and prospects for future research. Marine Pollution Bulletin. 40(5), 367-376.

[5] Taşdemir, Y. (2002). Marmara Denizi: Kirleticiler ve Çevre Açısından Alınabilecek Tedbirler. Uludağ Üniversitesi Mühendislik-Mimarlık Fakültesi Dergisi. 7, 39-45.

[6] Artüz, L.M. (2004). Marmara Denizinde Süregelen Karasal Kökenli Kirlenmenin Kökeni ve Boyutları. K.K.K. Jan. Çevre Birimi Konferans Metni.

[7] Ünübol, H.A. (2008). Gemlik Körfezi makro alglerinin bazı biyokimyasal özelliklerinin belirlenmesi. Yüksek Lisans Tezi. Uludağ Üniversitesi Fen Bilimleri Enstitüsü, Bursa.

[8] http://www.bursacevreorman.gov.tr ( 03.09.2011)

[9] Aksoy, E. (2011). Kişisel Görüşme. (Mudanya Belediyesi).

[10] http://www.fishbase.org

[11] Nelson J.S. (2006). Fishes of the World. 4th edition. John Wiley, NewYork. 601 p.

[12] Eschmeyer W.N. (1998). Catalog of Fishes. Published by the California Academy of Sciences. 1,2,3, San Fransisco, ISBN 0-940228-47-5.

[13] Eschmeyer W.N. (2006). http://www.calacademy.org/rese$\operatorname{arch} /$ ichthyology/catalog/fishcat/search.html

[14] Akşiray, F. Türkiye Deniz Balıkları ve Tayin Anahtarı II.
Baskı, 1987. İstanbul Üniversitesi Rektörlüğü Yayınları. Yay1n no: 3490, İstanbul.

[15] Yüce, R. (1998). Türkiye Denizlerinde Yaşayan Balıklar (200 Tür), Marmara Üniversitesi Yayın No:633, Doğa Bitkileri ve $\mathrm{Su}$ Ürünleri Araştırma, Uygulama Merkezi. Yayın No: 1. İstanbul. 20-463.

[16] Artüz, L.M. (2006). Marmara Denizi Araştırmaları Yöntemler ve 2006 Yaz Ölçümleri Ön Bulguları, Sualtı Bilim ve Teknoloji Toplantısı Bildiri Sözlü Bildiri.

[17] Altuğ G., Aktan Y., Oral M., Topaloğlu B., Dede A., Keskin C., İşinibilir M., Çardak M., Çiftçi P.S. (2011). Biodiversity of the Northern Aegean Sea and Southern part of the Sea of Marmara, Turkey. Marine Biodiversity Reports. Marine Biological Association of the United Kingdom. 4, 1-17. doi: $10.1017 / \mathrm{S} 1755267211000662$

[18] Bilecenoğlu M., Kaya M., Cihangir B., Çiçek E. (2014). An updated checklist of marine fishes of Turkey. Turkish Journal of Zoology. 38, 901-929.

[19] Ergüden E., Yuran C. (2013). İskenderun ve Mersin Körfezi yabancı balık faunasındaki son gelişmeler. BIBAD. 6:1, 1722.

[20] Çoker, T., Akyol, O. (2014). Gökova Körfezi (Ege Denizi) balık tür çeşitliliği üzerine bir değerlendirme. Ege J. Fish Aqua. Sci. (Su Ürünleri Dergisi). 31(3):161-166.

[21] Yaka, U. (2006). İzmit Körfezi balıkları ve morfolojik özellikleri üzerine araştırmalar. Yüksek Lisans Tezi. Marmara Üniversitesi Fen Bilimleri Enstitüsü. Biyoloji Programı. İstanbul.

[22] Keskin Ç. (2010). A review of fish fauna in the Turkish Black Sea. J.Black Sea/Mediterranean Environment. 16, 195-210.

[23] www.yenierdekgazetesi.com

[24] www.gelbalder.org

[25] Bat L., Erdem Y., Ustaoğlu S., Yardım Ö, Satılmış H.H. (2005). A study on the fishes of the central Black Sea coast of Turkey. J.Black Sea/Mediterranean Environment. 11, 281296.

[26] Kuşat M, Koca H.U. (2009). Antalya Körfezi'nde avcılık ile yakalanan balık türleri ve bunların işlenerek değerlendirilmesi. BIBBAD. 2, 41-47.

[27] Kır İ., Tekin-Ozan S., Çınar K. (2001). Antalya Körfezi ekonomik balıkları ve yoğunlukları üzerine bir araştırma. SD ̈U Fen Bil. Enst. Dergisi. 5(2), 133-138.

[28] Anonim (2002). Çevre ve Şehircilik Bakanlığı. Tabiat Varlıklarını Koruma Genel Müdürlüğü. Özel Çevre Koruma Bölgeleri. 22.12.2010 tarihli 27793 sayılı bakanlar kurulu kararı. 